\title{
A golden period for environmental soil chemistry
}

\author{
Donald L. Sparks
}

In many respects, the field of environmental soil chemistry has never been more important than today. Many of the critical environmental issues we face globally are linked to the changing climate, which is having profound impacts on the chemistry of soils. We have a poor understanding of how climate impacts not only chemical, but also physical, biological, and mineralogical properties and processes of soils. Figure 1 shows some of the major impacts of climate change on soils and water. Soils, globally, are under immense stress due to erosion, nutrient imbalances, salinization, desertification, pollution and acidification [1]. Our very best soils are being lost to development. In short, the fate of our soils and human security are inextricably linked [2]. The population of the world stands at 7.5 billion. It is expected to rise to 9-9.5 billion by 2050 and perhaps to 11 billion by 2100 . Megacities are sprouting up in many areas, particularly in Asia. These are cities of more than 10 million people. Much of the population growth is occurring in urban areas, in particular coastal regions. For example, more than $50 \%$ of the U.S. population lives in coastal areas. The latter areas are very susceptible to increased flooding and sea level rise.

With the impacts of climate and environmental change, there is incredible pressure to ensure an adequate food supply, especially for the most vulnerable regions, e.g., those in Africa. The production of enough food is dependent on adequate water, productive land, and in general healthy soils. A recent report from the Intergovernmental Panel on Climate Change [3] found that a half billion people live in locations that are seeing increased

*Correspondence: dlsparks@udel.edu

Delaware Environmental Institute, University of Delaware, Newark, DE 19716, USA desertification and soils are being lost between 10 and 100 times faster than they are forming. Climate change will exacerbate these threats even more due to flooding, droughts, storms and other extreme weather events, further affecting the food supply. The report also notes that presently more than 10 percent of the world's population is undernourished which could enhance cross-border migration and a quarter of humanity faces significant water crises.

Water quantity is particularly problematic with the increasing high temperatures and drought that we are seeing in areas such as the Western U.S., Africa, and many other parts of the world. Of the total water on Planet Earth, $96.5 \%$ is in oceans, bays, and glaciers. Groundwater, which is a major source of drinking water, comprises only $1.69 \%$ of the total water, and of this, only $0.76 \%$ is fresh water [4]. In a recent article in the New York Times [5], it was noted that 17 countries are under severe water stress. In addition to issues related to water scarcity, there are major challenges globally with water quality, related to excess nutrients such as nitrogen $(\mathrm{N})$ and phosphorus $(\mathrm{P})$ derived from organic wastes and inorganic fertilizers. In areas of high animal production, excess $\mathrm{N}$ and $\mathrm{P}$ in soils enter water bodies, causing hypoxia, resulting in algal blooms, fish kills and further impacts on tourism and even human health. Emerging organic contaminants such as antibiotics, hormones, perand polyfluoroalkyl substances (PFAS), and others and their impact on drinking water, are also of great concern, particularly as populations increase. All of these contaminants impact human health and our economic vitality.

Carbon dioxide levels have been increasing at an alarming rate, particularly over the last few decades. Prior to the industrial revolution, $\mathrm{CO}_{2}$ levels were about 280 ppm. By 2019 they had risen above 410 ppm, levels 


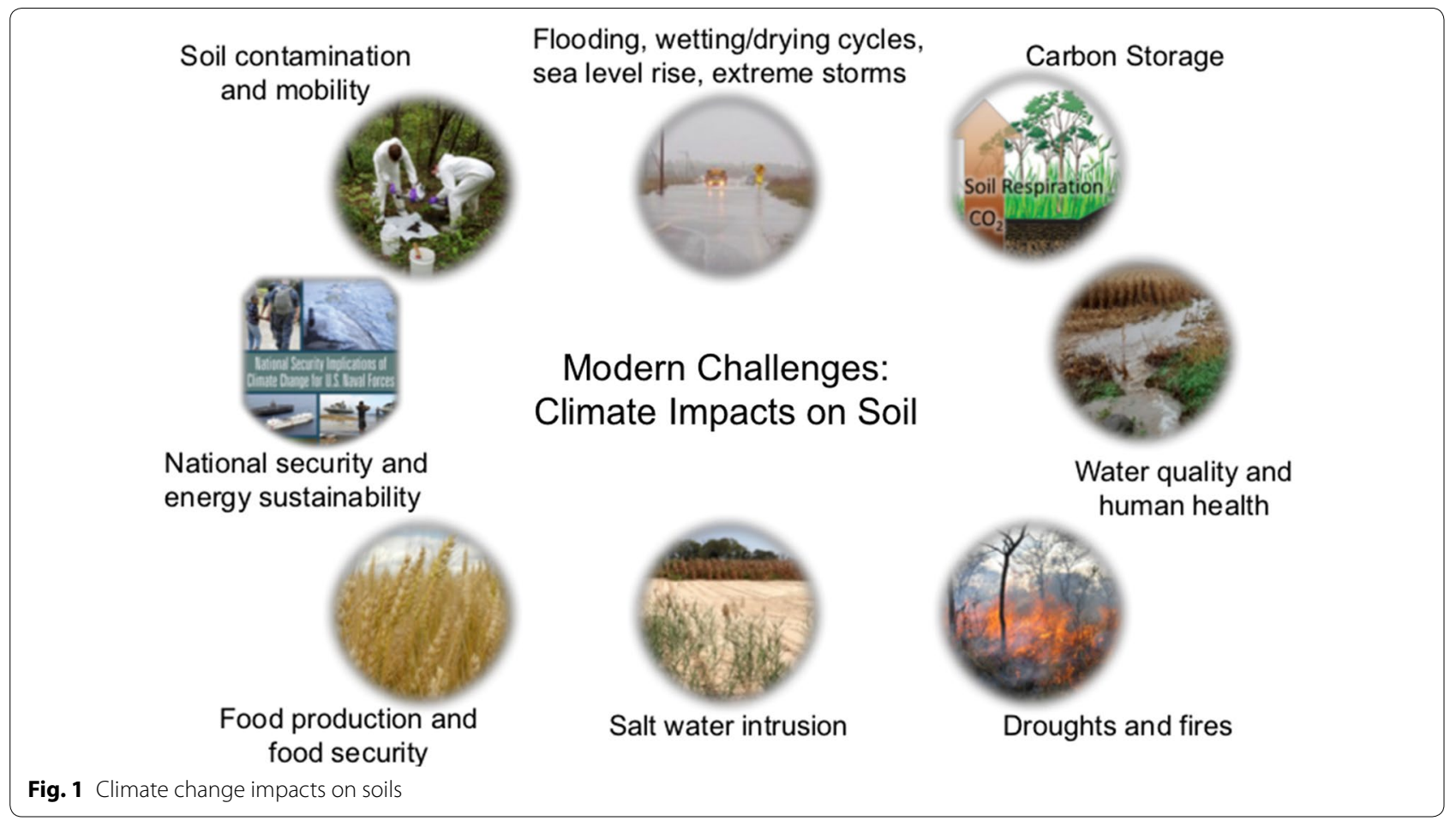

that last occurred 3 million years ago. Human activities are estimated to have caused an approximately $1.0{ }^{\circ} \mathrm{C}$ rise in global warming above pre-industrial levels, with a probable range of $0.8-1.2{ }^{\circ} \mathrm{C}$, and are likely to reach $1.5{ }^{\circ} \mathrm{C}$ between 2030 and 2052 if global warming continues at the present rate [6] (Fig. 2). The last several years have been the warmest on record. Many scientists have called this geological period in history the Anthropocene as conclusive scientific evidence shows that humans are having a major impact on Planet Earth. As Aldo Leopold so insightfully noted in 1933, "The reaction of land to occupancy determines the nature and duration of human civilization".

The increases in greenhouse emissions and rising temperatures have resulted in melting glaciers, less snow cover, diminishing sea ice, rising sea levels, ocean acidification, and increasing atmospheric water vapor. Extreme events such as intense rainfall, heat waves, and forest fires, and droughts are becoming more frequent [7]. In terms of sea level rise, the global sea level has risen $0.18-0.20 \mathrm{~m}$ since 1900 , with about half $(0.08 \mathrm{~m})$ of the rise occurring since 1993. The increasing sea level has resulted in more frequent flooding in coastal areas. Global average sea levels will continue to rise with model projections of a rise of $0.26-0.77 \mathrm{~m}$ by 2100 if global warming of $1.5{ }^{\circ} \mathrm{C}$ occurs [6]. The most vulnerable areas in the continental U.S. are along the Atlantic and Gulf Coasts. Subsidence, or land that is sinking, is compounding the problem, e.g., along the Mid-Atlantic Coast of the U.S. With increases in sea levels and flooding, there is increasing salinization of land and groundwater. Additionally, there are 2500 sites along the Atlantic and Gulf Coasts that are contaminated with metals, metalloids, and organic chemicals in areas that are heavily populated [8] (Fig. 3). It is not known how flooding and sea level rise, with its attendant salinity, will impact cycling of the contaminants and human health.

There is great concern about the impacts of rising temperatures on melting of permafrost soils. Permafrost soils sequester 1035 petagrams ( $\mathrm{Pg}$ ) of carbon (C) [9] in the top $3 \mathrm{~m}$ of soil, which represents about $70 \%$ of the current estimate for global soil C storage in the top $3 \mathrm{~m}$ (1500 Pg C) [10]. Research has already shown high labile $\mathrm{C}$ fractions released from permafrost soils that are thawing [11-13]. Plaza et al. [14], by quantifying $C$ related to fixed ash content, measured soil $C$ pool changes over a period of 5 years in warmed and ambient tundra ecosystems in Alaska. They found a 5.4\% loss of C/year. They attributed much of the loss to lateral hydrological export. In a recent paper, Hemingway et al. [15] found that tightly mineral bound $\mathrm{OC}$ persists for millennia. It is critical to understand the role of warming in release of $\mathrm{C}$, particularly $\mathrm{C}$ that is complexed with soil minerals such as iron oxides, which are major components for sequestering soil carbon [16-20]. 


\section{How close are we to $1.5^{\circ} \mathrm{C}$ ?}

Human-induced warming reached approximately $1^{\circ} \mathrm{C}$ above pre-industrial levels in 2017



Fig. 2 Global temperature change with time

\section{Major decadal research thrusts in environmental soil chemistry}

In view of the above environmental challenges, it seems clear that the major research frontiers in environmental soil chemistry over the next $5-10$ years will be heavily focused on the impacts of climate change on various soil chemical and mineralogical reactions and processes. Progress in these and other areas will result in large part due to rapid advances in analytical tools, data science, and modeling capabilities. As Nobel Laureate Sydney Brenner once said, "Progress (in science) depends on the interplay of techniques, discoveries, and ideas, probably in that order of importance [21].

Some of the major research thrusts and needs include:

Effects of sea level rise, salt water intrusion, and flooding on cycling of inorganic and organic contaminants such as metal (loid)s and nutrients

Fate and transport of antibiotics, hormones, PFAS and other emerging contaminants

Effects of warming of permafrost soils on carbon complexation with and release from soil minerals and emission of greenhouse gases

Modeling that integrates spatial and temporal scales
Advances in field-based spectroscopic techniques Development and deployment of real-time sensors Real-time investigations of soil chemical reactivity at the molecular scale

Coupled physical, chemical, and biological process studies

Mechanisms of mineral/microbe interactions Advances in understanding light element chemistry, e.g., $\mathrm{Al}, \mathrm{B}, \mathrm{Ca}$, and $\mathrm{S}$ in soils using new tender and soft X-ray techniques

\section{Challenges and opportunities in environmental soil chemistry research}

While there are so many exciting opportunities in the next decade in environmental soil chemistry research, there are still outstanding challenges now and in the future. One of the hallmarks of some of the most pioneering research in the field has been fundamental basic research. Soil chemists in the past were able to focus on a few areas for multiple periods such that they could "dig deeply" into the topic and become leading experts. This was made possible due to a continuity in funding for multiple periods. Over the past decade or more, institutional 


\section{Climate Change Impacted Soils}

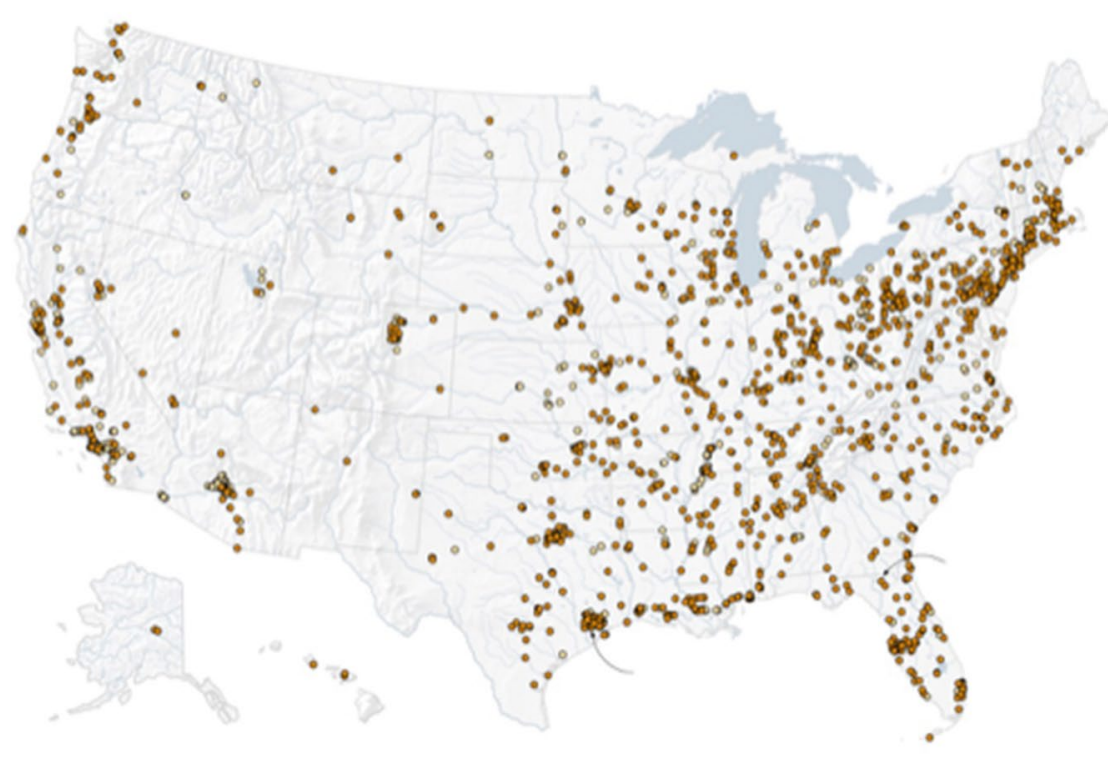

O Site in area at moderate risk of flooding

o Site in area at high risk of flooding

Fig. 3 Contaminated sites in the U.S. which are subject to flooding

funding has decreased along with funding from federal agencies and the private sector. Additionally, the focus areas of research that funders support also change frequently which causes scientists to shift on a frequent basis from one topic to another. Thus, it is difficult to work in a particular area for an extended period of time and be viewed as an expert. Such shifting in focus could deleteriously impact the long-term reputation of a scientist. My thoughts on the critical need for basic, fundamental research and taking a deep dive into a particular area are best summed up by Albert Einstein, who stated, "I have little patience with scientists who take a board of wood, look for its thinnest part, and drill a great number of holes where drilling is easy". There has also been a tendency for funding agencies to create large team science programs where multiple investigators, often from different institutions, pursue research on an interdisciplinary project. There is no question that many of the big challenges and opportunities in environmental soil chemistry research require an interdisciplinary approach. While soil chemists must focus on a few areas in depth at the fundamental level, they should take advantage of the exciting research opportunities that cross academic disciplines. However, the downside for individual scientists who pursue primarily large interdisciplinary science projects, especially early career scientists, is that their individual research products, i.e., refereed papers, often are not given the degree of credit that would result from publications that included only them and their students/ postdocs. The overall significant research impacts from large team science recently was questioned. In a recent paper by Wu et al. [22], more than 64 million papers, patents and software products over a period of 1954-2014 were examined. The results showed that small teams of scientists tended to produce impactful results and ideas while large teams developed existing ideas.

The environmental challenges we face are daunting. However, with challenges there are opportunities. The advances in analytical tools and cyberinfrastructure offer exciting opportunities for soil chemists to tackle and help solve some of the most pressing issues facing humankind. In short, the future of environmental soil chemistry is indeed bright.

\section{Acknowledgements \\ I am deeply indebted to Young-Shin Jun, Washington University in St. Louis, Mengqiang Zhu, University of Wyoming, and Derek Peak, University of \\ Saskatchewan, who served as editors of this Special Issue, and who invited me to contribute a feature article, and to all of the authors for their outstanding contributions}

\section{Authors' contributions}

DLS drafted the manuscript. The author read and approved the final manuscript. 


\section{Competing interests}

The author declares they have no competing interests.

Published online: 01 April 2020

\section{References}

1. FAO and ITPS (2015) Status of the World's soil resources (SWSR)-main report. Food and agriculture organization of the United Nations and intergovernmental technical panel on soils, Rome, Italy

2. Amundson R, Berhe AA, Hopmans JW, Olson C, Sztein AE, Sparks DL (2015) Soil and human security in the 21st century. Science 348:6235

3. IPCC (2019) Climate Change and land. An IPCC special report on climate change, desertification, land degradation, sustainable land management, food security and greenhouse gas fluxes in terrestrial ecosystems

4. Gleick PH (1996) Water Resources. In: Schneider SH (ed) Encyclopedia of climate and weather. Oxford Univ Press, New York, pp 817-823

5. Sengupta S, Cai W (2019) A Quarter of humanity faces looming water crises. The New York Times https://www.nytimes.com/interactiv e/2019/08/06/climate/world-water-stress.html

6. IPCC (2018) Global Warming of 1.5C. An IPCC special report on the impacts of global warming of 1.5C above pre-industrial levels and related global greenhouse gas emission pathways, in the context of strengthening the global response to the threat of climate change, sustainable development, and efforts to eradicate poverty

7. Global Change Research Program (2018) Impacts, risks, and adaptation in the US. Fourth National Climate Assessment, Washington, DC

8. USGCRP (2017) Climate science special report: fourth national climate assessment, vol 1. In: Wuebbles DJ, Fahey DW, Hibbard KA, Dokken DJ, Stewart BC, Maycock TK editors. US Global Change Research Program. Washington, DC https://doi.org/10.7930/j0j964j6

9. Schuur EA, Bockheim J, Canadell JG, Euskirchen E, Field CB, Goryachkin SV, Hagemann S, Kuhry P, Lafleur PM, Lee H (2008) Vulnerability of permafrost carbon to climate change: implications for the global carbon cycle. Bioscience 58:701-714

10. Scharlemann JP, Tanner EV, Hiederer R, Kapos V (2014) Global soil carbon: understanding and managing the largest terrestrial carbon pool. Carb Mngt. 5:81-91
11. Drake TW, Wickland KP, Spencer RG, McKnight DM, Striegl RG (2015) Ancient low-molecular-weight organic acids in permafrost fuel rapid carbon dioxide production upon thaw. Pro Nat Acad Sci. 112:13946-13951

12. Waldrop MP, Wickland KP, White lii R, Berhe AA, Harden JW, Romanovsky VE (2010) Molecular investigations into a globally important carbon pool: permafrost-protected carbon in Alaskan soils. Glob chang bio. $16: 2543-2554$

13. Burkert A, Douglas TA, Waldrop MP, Mackelprang R (2019) Changes in the active, dead, and dormant microbial community structure across a pleistocene permafrost chronosequence. Appl Environ Microbiol. 85:7

14. Plaza C, Pegoraro E, Bracho R, Celis G, Crummer KG, Hutchings JA, Hicks Pries CE, Mauritz M, Natali SM, Salmon VG, Schadel C, Webb EE, Schuur EAG (2019) Direct observation of permafrost degradation and rapid soil carbon loss in tundra. Nat Geosci 12:627-631

15. Hemingway JD, Rothman DH, Grant KE, Rosengard SZ, Eglinton TI, Derry LA, Galy W (2019) Mineral protection regulates long-term global preservation of natural organic carbon. Nature. 570:228-231

16. Chen C, Dynes JJ, Wang J, Sparks DL (2014) Properties of Fe-organic matter associations via coprecipitation versus adsorption. Environ Sci Tech. 48:13751-13759

17. Gu B, Schmitt J, Chen Z, Liang L, McCarthy JF (1994) Adsorption and desorption of natural organic matter on iron oxide: mechanisms and models. Environ Sci Tech. 28:38-46

18. Gu B, Schmitt J, Chen Z, Liang L, McCarthy JF (1995) Adsorption and desorption of different organic matter fractions on iron oxide. Geoch Cosm Act. 59:219-229

19. Lalonde K, Mucci A, Ouellet A, Gélinas Y (2012) Preservation of organic matter in sediments promoted by iron. Nat. 483:198-200

20. Lehmann J, Kinyangi J, Solomon D (2007) Organic matter stabilization in soil microaggregates: implications from spatial heterogeneity of organic carbon contents and carbon forms. Biogeochem. 85:45-57

21. Kenyon C (2019) Sydney Brenner (1927-2019). Pioneer of molecular biology and genetics. Science 364:638

22. Wu L, Wang D, Evans JA (2019) Large teams develop and small teams disrupt science and technology. Nature. 566:378-382

\section{Publisher's Note}

Springer Nature remains neutral with regard to jurisdictional claims in published maps and institutional affiliations.
Ready to submit your research? Choose BMC and benefit from:

- fast, convenient online submission

- thorough peer review by experienced researchers in your field

- rapid publication on acceptance

- support for research data, including large and complex data types

- gold Open Access which fosters wider collaboration and increased citations

- maximum visibility for your research: over $100 \mathrm{M}$ website views per year

At BMC, research is always in progress.

Learn more biomedcentral.com/submissions 